\title{
Accomplishing The Sustainable Development Goals as A Method in Women Confronting Terrorism
}

\author{
Dwia Aries Tina Pulubuhu ${ }^{1}$; Seniwati ${ }^{2 a}$; Andi Alimuddin ${ }^{3}$ \\ ${ }^{1}$ Department of Sociology, Hasanuddin Unversity, Makassar, Indonesia \\ ${ }^{2}$ Department of International Relations, Hasanuddin Unversity, Makassar, Indonesia \\ ${ }^{3}$ Department of Comunication, Hasanuddin Unversity, Makassar, Indonesia \\ ${ }^{a}$ Corresponding author: seniwati_2006@yahoo.co.id
}

\begin{abstract}
This paper focuses on the accomplishment of the sustainable development goals as a method in women to confront terrorism. Women have the crucial role in confronting terrorism. The purpose of this study is to investigate the efforts that are made by local governments in achieving SDGs. In the achievement of this research, qualitative research method is utilized. This research found that women empowerment measures relates to the ability of women engagement in the economic sector. Women need to be improved their knowledge on the various economic opportunities. The research supports the 2030 Sustainable Development Goals that has 17 goals. The accomplishment of SDGs, especially declining the poverty line of the society is one strategic initiative to fight terrorism.
\end{abstract}

Keywords - confront terrorism, women, economic opportunity, sustainable development goals

\section{INTRODUCTION}

The role of women in supporting the government to confront terrorism is enormous. Based on data of research, there are some activities that have been done by women in fighting terrorism. Therefore, the empowerment of women is very important. Bayeh in her research in Ethiopia found that "Women in Ethiopia did not get chance in various the issues to build their country. Women's empowerment in economic, social, political, and environment areas are needed to get gender equality" [4]. For this reason, the government needs to develop the competency of women in countering terrorism.

Empowering woman in handling important issues in her country become an international issue. Ahmed,et.al. state "ability and initiative of women are affected by the different roles, responsibilities and expectations of women and man in societies and cultures in participating in development projects. Therefore, government needs to focus on gender gaps and aim in providing equality for women in all areas of social provision..." [1]. This statement provides explanations of the need to empower women in all sectors, especially that are related to the social sector. The purpose of this study is to investigate the efforts that are made by local governments in achieving SDGs.

\section{RESEARCH METHOD}

In the conduct of this research, the writers utilized qualitative research method, with the collection of data as the main focus. In attaining the data needed, a number of specific methods are undergone. Among them, in-depth interview, larger group or focus group discussion, and on-line data gathering [8]. In addition to the methods above, observation and document analysis are also adopted to complete the data necessary for this research.

\section{RESULT AND DISCUSSION}

The government needs to work hard in the effort of gender awareness so that the effort of women empowerment can be achieved. The United Nations Conference found "Sustainable Development Goal 17 needs implementation and revitalize the Global Partnership to mobilize and share knowledge, technologies, expertise and financial resources in supporting the accomplishment of the sustainable development goals in all countries especially developing countries" [5]. Indonesia as one of developing countries still requires the global partnership in all sectors, especially in empowering women

Page and Czuba in their article said that empowerment has three components namely social, multi-dimensional, and a process. Multi-dimensional mean it occurs in some dimensions such as within economic, psychological, sociological, and other dimensions. Moreover, empowerment occurs in all levels such as community, group, and individual. Empowerment has definition in a social process if it occurs in relationship to others" [9]. This sentence describes that empowerment related with the ability of women in achieving their aim.

For that reason, women need a strategy in achieving their goals. Malhotra et.al. in her research found that there are five dynamic between connection and defines a pathway namely innovation, context and timing, diffusion, innovation systems, and women's empowerment and gender equality [7]. This statement illustrates that women need to know the innovation because it can give her opportunity in various issues that are developed from local, national and international level. In increasing the knowledge of innovation, women also need to vastly understand social innovations in order to be actively 
engaged in social justice that would result to advantages to the society. Women must participate in various sectors such as political, economic, technological, social, and environmental sectors. Such active participations would encourage women to be proactive in confronting terrorism activities.

Based on data from the Central Bureau of Statistics, the population of Pinrang Regency in 2014 was 364,087 people consist of 176,484 male and 187,603 female [3]. The data indicates that the demographic percentages of women are larger than men. This is certainly one of the strong reasons that women should be empowered especially in countering terrorism. World Bank in its report states that "gender equality" is smart economics and a core development objective in its own right. Productivity could be enhanced, development outcomes could be developed for the next generation, and institution is made more representative by greater gender equality [14].

Moreover, international organizations realized the prioritization of women empowerment such as the Beijing Platform for Action in 1995; Goal 3 of Millennium Development Goals in 2001; and the United Nations General Assembly adopted the Convention on the Elimination of All Forms of Discrimination against Women in 1979 (CEDAW). Alvarez states that the empowerment of women in politics and decision-making is the one of way to achieve the goal of gender equality [2]. Therefore, the United Nation in 1995 announced that the improvement of women's social, economic, and political status is very crucial in achieving the transparency, accountability, and sustainable development of governance and administration [2]. The involvement of women in all sectors such as the political, economic and social sectors are indispensable as stressed by the United Nations in 1995. Moreover, Alvarez in her research in politics and decision making as one of the ways in promoting gender equality and women empowerment. Every women needs to know the knowledge related to the process of decision making in multiple sectors in order to prevent family members engaging in terrorism activities.

Pinrang District Government conducted several strategies as the effort to empowering women in their activities. The government requests women as agents to peace process especially in confronting terrorism. Several workshops or religious lectures were conducted by the Pinrang District government in giving understanding to the public about the dangers of terrorism. Religious lectures are usually conducted in mosques, churches, and public area. This religious lecture gives information to the public about the actions of police and military forces in attacking terrorism and also the danger of terrorism. The police officers also invite the community to initiate measures in infiltrating terrorist activity agendas.

This research also conducted a workshop that is participated by government apparatus, society and representatives of the young generation. This workshop has explained the danger to society caused of terrorism. The purpose of this workshop is to educate and improve public knowledge of the danger of terrorist ideology and goal. The information attained in the workshop will be expected to prevent future cases of terrorist activities, with the involvement of women. Another goal of the workshop is to socialize economic sector especially entrepreneurship activities for people. Steven and Gunaratna [12]. In their book stated that there are five major sectors of the causes of political violence and terrorism such as military security, political security, economic security, societal security, and environmental security. Among the factors listed above, the factor of economic security requires more governmental attention.

Former President of Indonesia, Susilo Bambang Yudoyono, stated that the cause of terrorism emergence can be classified into a number of factors, including radical and extreme ideology, deviations from the religious teachings held, harsh living conditions, absolute poverty, and extreme economic circumstances [13]. Poverty is one of the roots of terrorism. The statement of Presiden Yudoyono highlighted that not only radical and extreme ideology causes terrorism, but also the deprived economic condition of the people. For this reason, local government needs to improve the economic sector through empowering women in economic agendas.

Women's empowerment in the economic sector needs attention from the local government. The United Nations member states adopted the 2030 agenda for Sustainable Development on September 25, 2016. The 2030 agenda for Sustainable Development has three dimensions: economy, social and environmental. The table below shows the Sustainable Development Goals.

TABLE 1. THE SDGS

\begin{tabular}{|c|c|}
\hline No. & Goal \\
\hline 1 & Overcoming poverty everywhere \\
\hline 2 & $\begin{array}{l}\text { Addressing hunger through food security and good nutrition and } \\
\text { promoting sustainable agriculture }\end{array}$ \\
\hline 3 & Ensure health through improved welfare for all ages \\
\hline 4 & $\begin{array}{l}\text { Ensure quality education through education coverage for all levels of } \\
\text { society }\end{array}$ \\
\hline 5 & Achieving gender equality through empowerment of all women \\
\hline 6 & $\begin{array}{l}\text { Ensure availability and sustainable management of water and } \\
\text { sanitation for all levels of society }\end{array}$ \\
\hline 7 & $\begin{array}{l}\text { Ensuring access to affordable, reliable, sustainable and modern } \\
\text { energy for all walks of life }\end{array}$ \\
\hline 8 & $\begin{array}{l}\text { Promote the sustainability of economic growth through increased } \\
\text { productivity for all levels of society }\end{array}$ \\
\hline 9 & $\begin{array}{l}\text { Build resilient infrastructure, promoting inclusive and sustainable } \\
\text { industrialization and foster innovation }\end{array}$ \\
\hline 10 & Reduced inequality within countries and between countries \\
\hline 11 & $\begin{array}{l}\text { Make urban areas and human settlements inclusive, sustainable, } \\
\text { resilient, and safe }\end{array}$ \\
\hline 12 & Ensures sustainable consumption and production patterns \\
\hline 13 & Take action for combat climate change and its impacts \\
\hline 14 & $\begin{array}{l}\text { Conserving and sustainably use the seas, oceans, and marine } \\
\text { resources for sustainable development }\end{array}$ \\
\hline 15 & $\begin{array}{l}\text { Protecting, restoring and promoting sustainable use of halt } \\
\text { biodiversity loss, combat desertification, sustainably manage forests, } \\
\text { terrestrial ecosystem, and halt and reverse land degradation }\end{array}$ \\
\hline 16 & $\begin{array}{l}\text { Promoting peaceful and inclusive societies for providing access to } \\
\text { justice for all, sustainable development, building effective, } \\
\text { accountable and inclusive institutions for all levels }\end{array}$ \\
\hline 17 & $\begin{array}{l}\text { Strengthening the means of implementation and revitalizing the } \\
\text { Global Partnership for Sustainable Development }\end{array}$ \\
\hline
\end{tabular}


SDG is one of the ways in countering terrorism. Each element of SDGs supports women's movements and aims to address economic inequality and poverty. These principles will make people do not to support terrorist activities. The figure below illustrates the poverty rate per district in South Sulawesi Province.

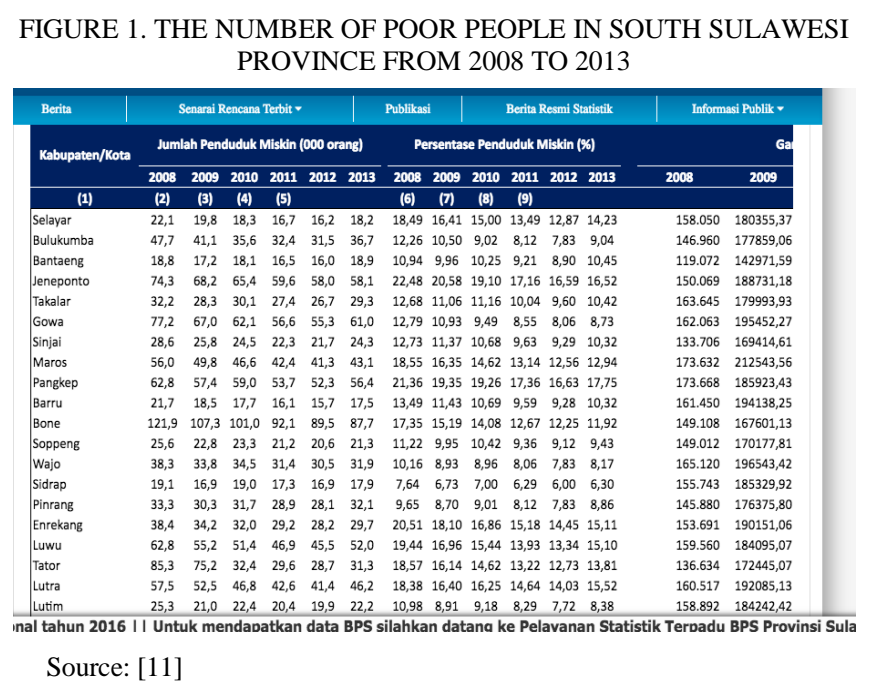

Based on the above data, Pinrang District is smaller number of poor people than some other districts. Nevertheless, the number of poor people increases from 28.1 percent in 2012 to 32.1 percent in 2013. This situation is caused by high population growth rate, income gap, lack of new employment and access to employment and lack of innovation and not optimum increase of production value of each business group [10].

The above condition gives a conclusion that SDGs is less achieved. This condition needs serious attention from the government. This situation will make the community especially the younger generation will be easily influenced by the movements of terrorist organizations. Therefore, there are several items that must be done under the name of advancing women's rights and gender equality program. One is SDGs goal 8 on the sustainable economic growth through the enhancement of productivity for all levels of the society.

Although Indonesia is a developing country, the economic opportunity must give more chances to women participation. The women engagement in economic sectors can certainly promote regional economic advantages and it will effect to the accomplishment of SDG goals. The local government is strongly suggested to formulate local-policies to achieve the target of the SDGs.

\section{CONCLUSION}

The women engagement in economic sector is a key factor in achieving SDGs. The Pinrang District Government needs to have local-policy and program action to decrease poverty condition of the people. One policy and program should be focused to the improvement of women activities in economic sector. The better economic condition of the family in Pinrang Regency can be achieved by woman engagement in economic activities. This effort will be very useful to prevent or confront the family member to involve in terrorism.

This study focuses only on religious and economic activities as an effort to achieve SDGs. Maximum achievement is one indicator of society will not support terrorism activities anymore. Therefore, future research needs to look at the education sector. Community economic activities can work well if are supported by an educated community.

\section{ACKNOWLEDGMENT}

We wish to express our gratitude to Hasanuddin University for its full support to fund the research activities in Pinrang Regency. We wish also special thanks and appreciation to Pinrang Regency Government, Police of Pinrang Regency, and people who join entrepreneurship sector in supporting of our data during in pursuing the research activities.

\section{REFERENCES}

[1] J. Ahmed, A. Angeli, A. Biru, and S. Salvini. Gender Issues, Population and Development in Ethiopia in-Depth Studies From The 1994 Population and Housing Census in Ethiopia, Italian Multy-Bi Research Project ETH/92/P01. Ethiopia, Addis Ababa: Central Statistical Authority (CSA), Italy, Roma: Institute for Population ResearchNational Research Council (Irp-Cnr). 2001.

[2] M.L. Alvarez, From Unheard Screams to Powerful Voices: A Case Study of Women's Political Empowerment in The Philippines. Seoul,Korea: Thesis. 2013.

[3] Badan Pusat Statistik. Kabupaten Pinrang Dalam Angka. 2015.

[4] E. Bayeh, "The Role of Empowering Women and Achieving Gender Equality to The Sustainable Development of Ethiopia." Pacific Science Review B: Humanities and Social Sciences. 2. 2016. Pp.37-42.

[5] Environmental Protection Authority. United Nations Conference on Sustainable Development (Rio+20). National Report of Ethiopia 2012. 2012.

[6] V. Esquivel, and C. Sweetman. "Gender and the Sustainable Development Goals.” Gender \& Development. Vol.24. No. 1, 2016. 1-8.

[7] A. Malhotra, J. Schulte, P. Patel, and P. Petesch. Innovation for Women's Empowerment and Gender Equality. North Washington: ICRW (International Center for Research on Women). 2009.

[8] J. Mason, Qualitative Researching: Second Edition. Londong: SAGE Publications. 2002.

[9] N. Page, and C.E.Czuba. "Empowerment: What Is It?. “ Journal of Extension. October, 1999 Volume 37,Number 5.

[10] RPJMD Kabupaten Pinrang. Rencana Pembangunan Jangka Menengah Daerah Kabupaten Pinrang tahun 2014-2019. 2017.

[11] Statistics Indonesia. Jumlah dan Persentase Penduduk Miskin Menurut Kabupaten di Provinsi Sulawesi Selatan. Sulawesi Selatan Province. 2016.

[12] G.C. Steven, and R. Gunaratna. Counterterrorism: A Reference Handbook. California: ABC-CLIO. 2004.

[13] Viva. Tiga Penyebab Munculnya Terorisme Menurut SBY. http://www.viva.co.id/berita/nasional/79144-tiga-penyebab-munculnyaterorisme-menurut-sby. 2017. Retrieved 1 September 2017.

[14] World Development Report. Gender Equality and Develoment. Washington,DC: The World Bank. 2012. 